\title{
ANALISIS KELAYAKAN INVESTASI PENAMBAHAN MESIN FRAIS BARU PADA CV. XYZ
}

\author{
Febri Muhammad Rachadian ${ }^{1)}$, Ereika Arie Agassi ${ }^{2)}$, Wahyudi Sutopo ${ }^{3)}$ \\ ${ }^{1,2)}$ Mahasiswa Jurusan Teknik Industri, Universitas Sebelas Maret \\ ${ }^{3)}$ Laboratorium Sistem Logistik dan Bisnis, Jurusan Teknik Industri, Universitas Sebelas Maret \\ Jl. Ir. Sutami 36A, Kentingan, Surakarta 57126, Indonesia \\ febri_rachadian@yahoo.com, ereiaga@gmail.com, sutopo@uns.ac.id
}

\begin{abstract}
Abstrak
Perkembangan teknologi sangat pesat sehingga dunia perindustrian harus mengikuti perkembangannya. Penerapan teknologi diharapkan dapat meningkatkan proses produksi sehingga dapat menghasilkan produk yang berkualitas. Pada industri pembuatan mesin cetak di CV XYZ, mesin-mesin yang digunakan telah hampir lebih dari 20 tahun. Ada indikasi bahwa mesin-mesin tersebut sudah lewat umur pakainya. Alternatif yang digunakan selama ini ialah penggantian komponen yang rusak. Peneliti ingin membandingkan alternative tersebut dengan penambahan mesin frais baru. Untuk itu diperlukan analisis kelayakan investasi penambahan mesin baru. Dalam perkiraan kurun waktu 10 tahun dan suku bunganya $15 \%$ dengan menggunakan NPV, penambahan mesin frais menarik sebesar Rp 461.201.000 dibandingkan penggantian komponen yang rusak sebesar Rp 211.227.000. Sebaliknya pada PBP, penggantian komponen yang rusak masih mengungguli dengan 1 tahun 4 bulan dibandingkan penambahan mesin frais baru selama 2 tahun 1 bulan. Begitupun juga PI penggantian komponen yang rusak masih menarik sebesar 4,2 dibandingkan PI penambahan mesin frais baru sebesar 2,56. Dapat disimpulkan bahwa dalam jangka waktu 10 tahun, alternatif penggantian komponen yang rusak masih lebih baik dibandingkan penambahan mesin frais baru. Namun, untuk investasi jangka panjang, mungkin saja alternatif penambahan mesin frais baru lebih menarik.
\end{abstract}

Kata Kunci: penggantian komponen rusak, mesin frais baru, mesin cetak

\begin{abstract}
The rapid development of technology makes the world of industry must follow its development. Application of technology is expected to improve the production process so it can be produce a quality product. On the industrial manufacture of printing machines in CV XYZ, the machines have been used almost more than 20 years. There are indications that those machines passed the age lifetime. The alternatives that have been used during this time are the replacement of defective parts. Researchers wanted to compare these alternatives with the addition of a new milling machine. It required the addition of investment feasibility analysis of a new machine. The approximate period of 10 years and interest rates of $15 \%$ by using the NPV, the addition of milling machines attract Rp 461.201 million compared to replacement of defective parts of Rp 211.227 million. In contrast to the PBP and PI, the replacement of defective parts that are still ahead for 1 year 4 months and 4.2 compared to the addition of a new milling machine for 2 years and 1 month and 2.56. That can be concluded within 10 years, the alternative replacement of defective parts is still better than the addition of a new milling machine. However, for long-term investment it may be an alternative addition of a new milling machine more interesting.
\end{abstract}

Key word: replacement of defective parts, new milling machine, printing machine

\section{PENDAHULUAN}

Penerapan teknologi produksi pada suatu perusahaan manufaktur dapat digunakan untuk memperbaiki dan meningkatkan efisiensi proses dalam rangka menghasilkan produk yang berkualitas (Umar, 2005; Widiyanthi, 2007; Subagyo, 2008). Peralatan produksi memiliki umur hidup atau dapat disebut umur pakai. Ketika suatu alat telah melewati umur pakainya, maka performansinya akan menurun. Hal ini akan berdampak pada kualitas produk yang dihasilkan dan efisiensi waktu dalam pengerjaan produk.

Bagi konsumen dari perusahaan manufakur, kepuasan mereka ialah menerima produk dengan kualitas baik dan 
tepat waktu. Jika terjadi kecacatan atau keterlambatan waktu pengerjaan pesanan, kepercayaan konsumen pada industri itu pasti berkurang. Ada dua faktor yang terlibat dalam suatu investasi peralatan yaitu waktu dan resiko. Menurut Pujawan (2008), pada jenis investasi tertentu waktu lebih berperan, sementara pada jenis investasi yang lain faktor resiko lebih dominan. Penelitian tentang aspek pasar dan pemasaran perlu diadakan penelitian terhadap beberapa hal yang perlu diperhatikan yaitu permintaan, penawaran, proyeksi permintaan dan penawaran, proyeksi penjualan, produk (barang/jasa), segmentasi pasar, strategi dan implementasi pemasaran (Subagyo, 2008; Mukti, 2009).

Studi kelayakan bisnis merupakan penelitian terhadap rencana bisnis yang tidak hanya menganalisis layak atau tidak layak bisnis dibangun, tetapi juga pada saat dioperasionalkan secara rutin dalam rangka pencapaian keuntungan yang maksimal untuk waktu yang tidak ditentukan (Umar, 2005; Afandi, 2009). Investasi pada hakekatnya merupakan penempatan sejumlah dana pada saat ini dengan harapan untuk memperoleh keuntungan dimasa yang akan datang (Halim, 2005). Kasmir dan Jakfar (2007) membagi investasi menjadi dua jenis, yaitu:

1. Investasi nyata (real investment)

Investasi nyata atau real investment merupakan investasi yang dibuat dalam harta tetap (fixed asset) seperti tanah, bangunan, peralatan, atau mesin-mesin.

2. Investasi finansial (financial investment) Investasi finansial atau financial investment merupakan investasi dalam bentuk kontrak kerja, pembelian sahma atau obligasi atau surat berharga lainnya seperti sertifikat deposito.

Pada perusahaan pembuatan mesin cetak di CV XYZ, mesin-mesin yang digunakan telah hampir lebih dari 20 tahun. Ada indikasi bahwa mesin-mesin tersebut sudah lewat umur pakainya. Hal ini dapat dilihat dengan adanya keterlambatan produksi dikarenakan banyaknya komponen yang rusak sehingga harus menunggu untuk diperbaiki terlebih dahulu. Sejauh ini yang dilakukan perusahaan hanya melakukan penggantian komponen yang rusak. Namun perusahaan belum memikirkan tentang perhitungan keuntungan dengan kerugian menggunakan alternatif ini.

Pada artikel ini dilakukan analisis perbandingan alternatif yang digunakan perusahaan dengan alternatif usulan yaitu investasi penambahan mesin baru. Dari hasil penelitian ini diharapkan CV. XYZ dapat mengetahui alternatif investasi dan dapat memilih alternatif yang terbaik dengan menggunakan metode-metode analisis kelayakan investasi sehingga CV. $\mathrm{XYZ}$ dapat memaksimalkan keuntungan perusahaannya.

\section{METODE PENELITIAN}

\section{Objek Penelitian}

Objek penelitian ini adalah CV. XYZ, merupakan perusahaan yang bergerak di bidang manufaktur sebagai general supplier mesin-mesin cetak yang menggunakan mesin lama seperti yang disajikan pada Gambar 1.

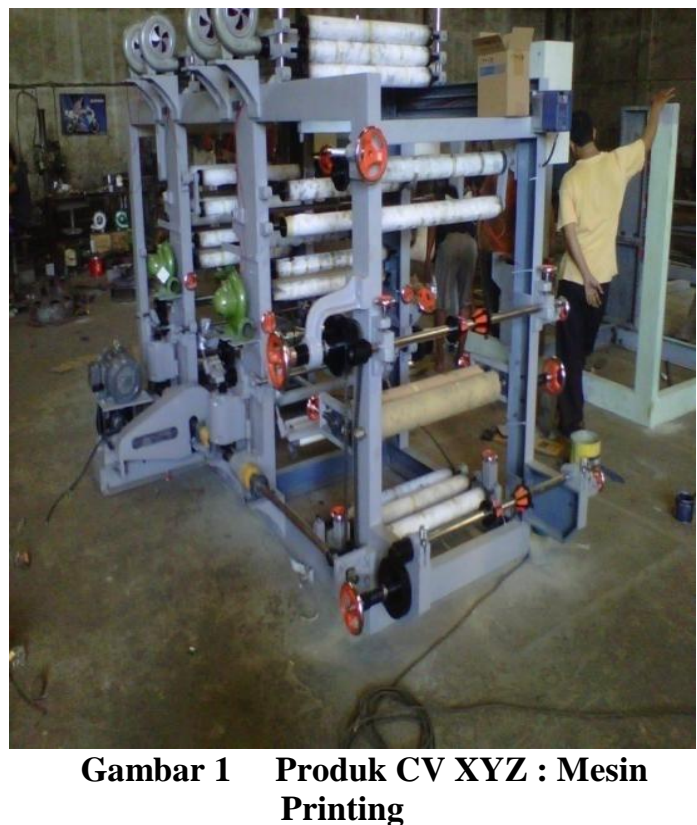

2. Jenis dan Teknik Pengumpulan Data Adapun jenis data dalam penelitian ini ialah data kuantitatif berupa data perkiraan cashflow alternatif penggantian komponen rusak dan data perkiraan cashflow alternatif penambahan mesin frais baru dalam 10 tahun dengan tingkat bunga $15 \%$. Selain itu diambil data kualitatif berupa 
keterangan, informasi, penjelasan, pendapat dan tanggapan dari pemilik. Sedangkan jenis data menurut sumbernya adalah data primer yang diperoleh secara langsung dari responden atau tangan pertama dan data sekunder yang diperoleh melalui studi pustaka mengenai investasi.

3. Metode Analisis Data

Alat Analisis Kelayakan Investasi

a. Metode PP (Payback Period)

Metode Payback Period

merupakan teknik penilaian terhadap jangka waktu (periode) pengembalian investasi suatu proyek atau usaha. Jumlah investasi x 12 bulan $=$ Payback Period $=$ Aliran Kas Bersih. Kriteria penilaian pada payback period adalah :

o Jika Payback period-nya < waktu maksimum, maka usulan proyek tersebut dapat diterima.

o Jika Payback period-nya > waktu maksimum, maka usulan proyek tersebut ditolak.

b. Metode NPV (Net Present Value)

Merupakan metode analisis keuangan yang memperhatikan adanya perubahan nilai uang karena faktor waktu; proyeksi arus kas dapat dinilai sekarang (periode awal investasi) melalui pemotongan nilai dengan faktor pengurang yang dikaitkan dengan biaya modal (persentase bunga).

NPV $=$ Total PV Aliran Kas Bersih Total PV Investasi

Kriteria penilaian NPV adalah :

o Jika NPV > 0, maka investasi diterima.

o Jika NPV < 0, maka investasi ditolak.

c. Metode PI (Profitabilitas Indeks)

Indeks profitabilitas adalah rasio atau antara jumlah nilai sekarang arus kas selama umur ekonomisnya dan pengeluaran awal proyek.

Total PV Kas Bersih

PI = Total Investasi

Kriteria untuk Profitabilitas Indeks :

o Proyek dinilai layak jika PI > atau

$=1,00$, sebaliknya

o Dinilai tidak layak jika PI $<1,00$

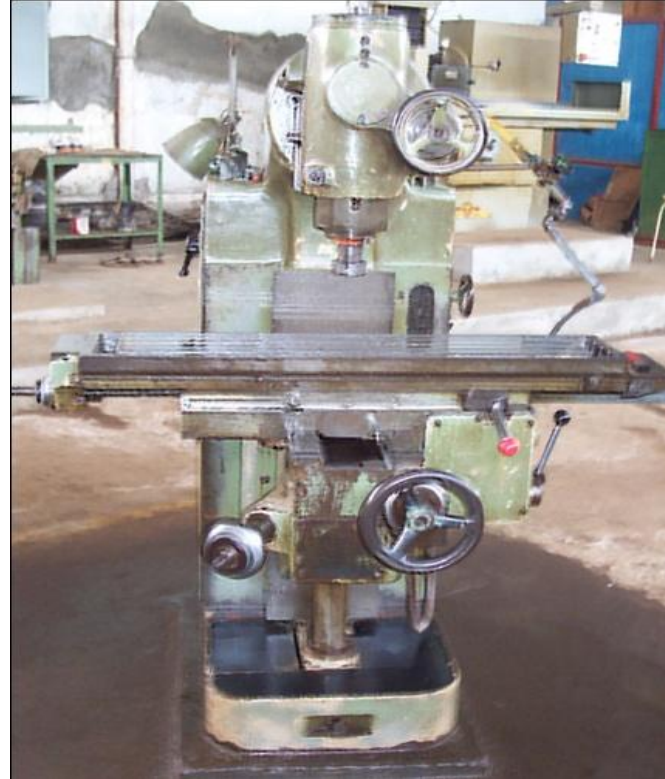

Gambar 2 Mesin Frais

\section{HASIL PENELITIAN}

Proposal bisnis yang dirancang yaitu proposal bisnis untuk membandingkan kondisi usulan (alternatif 2) yaitu menambah mesin freis baru (Gambar 2) atau tetap melakukan penggantian komponen yang rusak saja (alternatif 1).

\section{Analisis pengambilan keputusan dengan indikator Net Present Value}

Rancangan proposal bisnis ini menggunakan indikator-indikator dalam pengambilan keputusan alternatif untuk mengetahui alternatif yang terbaik. Indikatornya ialah Net Present Value, Payback Period dan Profitability Index. Hasil analisis cash flow alternatif penambahan mesin freis baru dan diagram cashflow penggantian komponen yang rusak dinyatakan pada Table 1, Gambar 3 dan Gambar 4

Tabel 1 Cashflow masing-masing Alternatif

\begin{tabular}{|c|c|c|}
\hline Tahun & Alternatif 1 & Alternatif 2 \\
\hline 0 & Rp - 180.000 .000 & $\mathrm{Rp}-50.000 .000$ \\
\hline 1 & $\operatorname{Rp} 100.000 .000$ & $\operatorname{Rp} 40.000 .000$ \\
\hline 2 & Rp 120.000.000 & Rp 55.000.000 \\
\hline 3 & Rp 150.000 .000 & $\operatorname{Rp} 60.000 .000$ \\
\hline 4 & Rp 130.000.000 & $\operatorname{Rp} 70.000 .000$ \\
\hline 5 & Rp 140.000.000 & $\mathrm{Rp} 45.000 .000$ \\
\hline 6 & Rp 145.000.000 & Rp 50.000.000 \\
\hline 7 & Rp 160.000 .000 & $\operatorname{Rp} 60.000 .000$ \\
\hline 8 & Rp 130.000.000 & Rp 50.000.000 \\
\hline 9 & Rp 100.000.000 & $\mathrm{Rp} 40.000 .000$ \\
\hline 10 & Rp 110.000.000 & $\mathrm{Rp} 45.000 .000$ \\
\hline
\end{tabular}




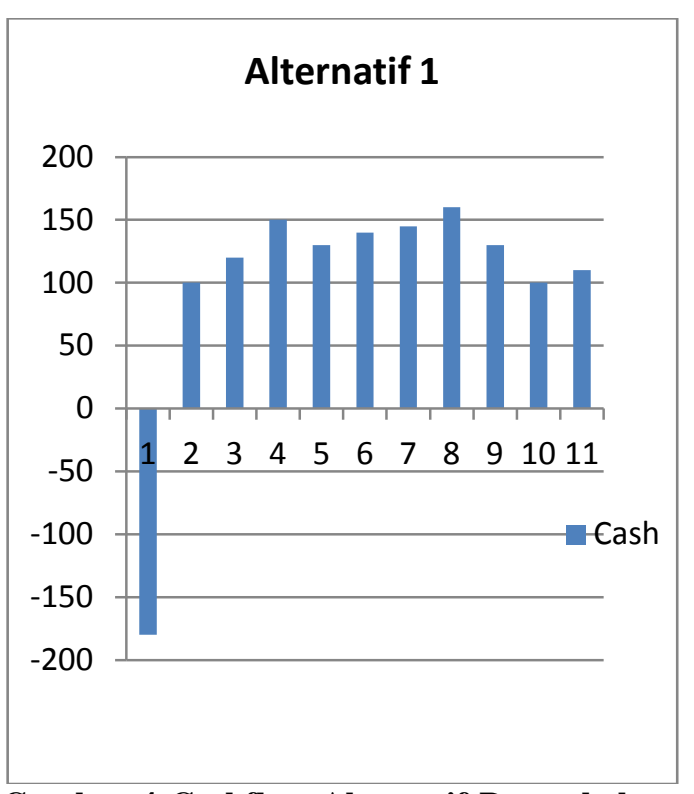

Gambar 4 Cashflow Alternatif Penambahan Mesin Freis Baru

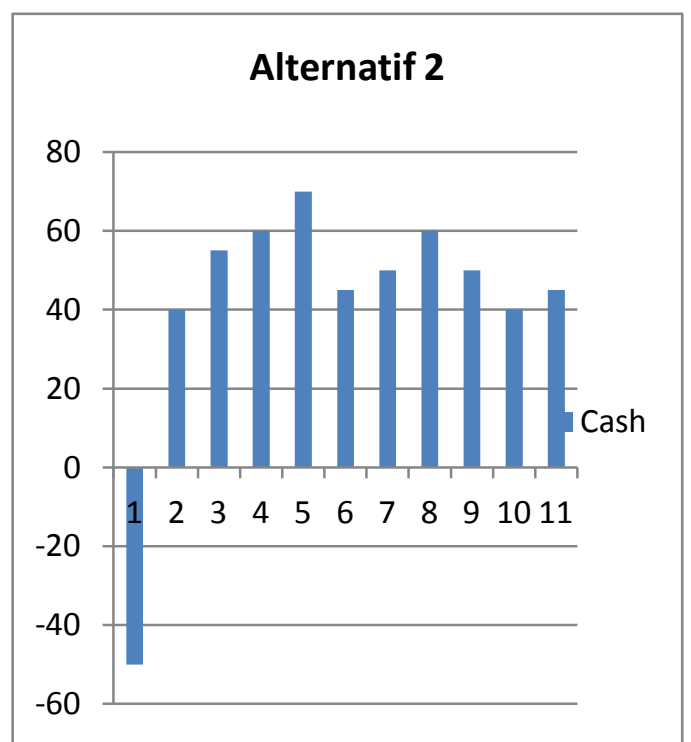

Gambar 5 Cashflow Alternatif Penggantian Komponen yang Rusak

\section{a. Net Present Value}

Net Present Value (NPV) ialah nilai sekarang dari seluruh aliran kas mulai sekarang sampai akhir proyek. Proyek diterima apabila NPV >0 atau NPV yang paling besar. Kelebihan dari NPV:

1. Memperhitungkan nilai uang karena faktor waktu sehingga lebih realistis terhadap perubahan harga.

2. Memperhitungkan arus kas selama usia ekonomis investasi.

3. Memperhitungkan adanya nilai sisa investasi.
Sedangkan kelemahan dari NPV adalah:

1. Lebih sulit dalam penggunaan perhitungan.

2. Derajat kelayakan selain dipengaruhi arus kas juga oleh faktor usia ekonomis investasi.

Dari Tabel 2 diketahui bahwa NPV untuk alternatif penggantian mesin freis baru sebesar Rp 461.201.000 sedangkan NPV untuk alternatif penggantian komponen yang rusak hanya Rp 211.227.000. Hal ini dapat disimpulkan bahwa alternatif penggantian mesin frais baru lebih menarik karena $\mathrm{NPV}_{\mathrm{A}}>\mathrm{NPV}_{\mathrm{B}}$.

$$
\begin{aligned}
\mathrm{NPV}_{\mathrm{A}} & =\mathrm{F}_{\mathrm{n}}(1+\mathrm{i})^{-\mathrm{n}}-\mathrm{P} \\
& =\mathrm{Rp} 641.201 .000-\mathrm{Rp} 180.000 .000 \\
& =\mathrm{Rp} 461.201 .000,00 \\
\mathrm{NPV}_{\mathrm{B}} & =\mathrm{Fn}(1+\mathrm{i})^{-\mathrm{n}}-\mathrm{P} \\
& =\operatorname{Rp} 261.616 .000-\mathrm{Rp} 50.000 .000 \\
& =\operatorname{Rp} 211.227 .000,00
\end{aligned}
$$

\begin{tabular}{|c|c|c|}
\hline \multirow{2}{*}{$\begin{array}{l}\text { Akhir } \\
\text { tahun }\end{array}$} & \multicolumn{2}{|c|}{ Aliran kas netto } \\
\hline & Alternatif 1 & Alternatif 2 \\
\hline 0 & $\mathrm{Rp}-180.000 .000$ & $\mathrm{Rp}-50.000 .000$ \\
\hline 1 & Rp 86.956 .000 & Rp 34.782 .000 \\
\hline 2 & Rp 90.737 .000 & $\mathrm{Rp} 41.588 .000$ \\
\hline 3 & Rp 98.627.000 & Rp 39.451.000 \\
\hline 4 & $\mathrm{Rp} \quad 74.328 .000$ & $\mathrm{Rp} \quad 40.023 .000$ \\
\hline 5 & Rp 69.604 .000 & Rp 22.373 .000 \\
\hline 6 & Rp $\quad 62.687 .000$ & Rp 21.616.000 \\
\hline 7 & Rp 60.149 .000 & Rp 22.556 .000 \\
\hline 8 & Rp 42.497 .000 & Rp 16.345 .000 \\
\hline 9 & Rp 28.426 .000 & Rp 11.370 .000 \\
\hline 10 & Rp 27.190 .000 & Rp 11.123 .000 \\
\hline Total & Rp 461.201.000 & Rp 211.227 .000 \\
\hline
\end{tabular}

Tabel 2 Perhitungan Net Present Value

\section{b. Payback Period}

Payback Period (PBP) ialah jangka waktu pengembalian biaya awal. Semakin cepat pengembaliannya maka alternatif tersebut lebih menarik dibandingkan dengan alternatif lainnya. Kelebihan dari metode payback Period yaitu:

1. Mudah dalam penggunaan dan perhitungan.

2. Berguna untuk memilih investasi yang mana yang mempunyai masa pemulihan tercepat. 
3. Masa pemulihan modal dapat digunakan untuk alat prediksi resiko ketidakpastian pada masa mendatang. Masa pemulihan tercepat memiliki resiko lebih kecil dibandingkan dengan masa pemulihan yang relatif lebih lama.

Sedangkan kelemahannya PBP ialah :

1. Mengabaikan adanya perubahan nilai uang dari waktu ke waktu.

2. Mengabaikan arus kas setelah periode pemulihan modal dicapai.

3. Mengabaikan nilai sisa proses.

4. Sering menjebak analisator jika biaya modal atau bunga kredit tidak diperhitungkan dalam arus kas yang menyebabkan usaha tidak likuid.

Pada alternatif penggantian mesin frais baru didapatkan 2 tahun 1 bulan sedangkan alternatif penggantian komponen rusak ialah 1 tahun 4 bulan. Dapat disimpulkan bahwa alternatif penggantian komponen yang rusak lebih menarik dibandingkan alternatif penggantian mesin frais baru karena tingkat pengembalian biaya awalnya lebih cepat.

\section{c. Profitability Index}

Profitability Index (PI) ialah rasio antara nilai ekivalen tahunan dari aliran kas pendapatan dengan nilai ekivalen tahunan dari aliran kas biaya (Tabel 3 dan Tabel 4). Alternatif yang terbaik ialah alternative yang memiliki nilai PI terbesar. Alternatif penggantian mesin frais baru didapatkan 3,01 sedangkan alternatif penggantian komponen yang rusak memiliki nilai PI sebesar 2,68. Dalam kasus ini, PI alternatif penggantian komponen yang rusak lebih menarik dibandingkan alternatif penambahan mesin frais baru karena $\mathrm{PI}_{\mathrm{A}}$ $<\mathrm{PI}_{\mathrm{B}}$.

$$
\begin{aligned}
\mathrm{PI}_{\mathrm{A}} & =\mathrm{NPV}_{\mathrm{A}} / \mathrm{ICO} \\
& =\mathrm{Rp} 461.201 .000 / \mathrm{Rp} 180.000 .000 \\
& =2,56 \\
\mathrm{PI}_{\mathrm{B}} & =\mathrm{NPV} \mathrm{B}_{\mathrm{B}} / \mathrm{ICO} \\
& =\mathrm{Rp} 211.227 .000 / \mathrm{Rp} 50.000 .000 \\
& =4,2
\end{aligned}
$$

Tabel 3 Profitability Index Kedua Alternatif PROFITABILTY INDEX

\begin{tabular}{lc}
\hline Alternatif 1 & 2,56 \\
Alternatif 2 & 4,2 \\
\hline
\end{tabular}

Tabel 4 Perbandingan Kedua Alternatif Method Alternatif Alternatif Result

\begin{tabular}{cccc} 
& $\mathbf{1}$ & $\mathbf{2}$ & \\
\hline NPV & Rp & Rp & Alt. 1 \\
& $461.201 \mathrm{k}$ & $211.227 \mathrm{k}$ & \\
PBP & 2 tahun 1 & 1 tahun 4 & Alt. 2 \\
& bulan & bulan & \\
PI & 2,56 & 4,2 & Alt. 2 \\
\hline
\end{tabular}

Berdasarkan analisis terhadap proyeksi keuangan yang ada, dapat didapatkan bahwa rencana investasi dalam penambahan mesin frais baru masih kurang menarik. Namun dari segi Net Present Value, penambahan mesin frais menarik sebesar Rp 461.201.000 dibandingkan penggantian komponen yang rusak yang hanya sebesar Rp 211.227.000 dalam perkiraan kurun waktu 10 tahun dan suku bunganya $15 \%$. Sebaliknya pada tingkat pengembalian biaya awalnya atau Payback Period, penggantian komponen yang rusak masih mengungguli dengan tingkat pengembalian yang hanya memerlukan waktu 1 tahun 4 bulan dibandingkan penambahan mesin freis baru selama 2 tahun 1 bulan. Begitupun juga Profitability Index alternatif penggantian komponen yang rusak masih menarik dengan besarnya 4,2 dibandingkan profitability index penambahan mesin freis baru yang hanya sebesar 2,56. Dalam jangka waktu 10 tahun, alternatif yang biasanya dilakukan oleh perusahaan yaitu penggantian komponen yang rusak masih lebih baik dibandingkan penambahan mesin frais baru. Namun, untung investasi jangka panjang, mungkin saja alternatif penambahan mesin frais baru lebih menarik, belum lagi perhitungan biaya maintenance, biaya overtime dan biaya-biaya lainnya yang membuat alternatif penggantian komponen menjadi tidak menarik. 


\section{KESIMPULAN}

Analisis kelayakan investasi dapat digunakan untuk membuktikan usulan penggantian mesin produksi yang baru memberikan manfaat lebih bagi perusahaan. Perusahaan dapat menekan waktu produksi sehingga produktivitas perusahaan meningkat. Perusahaan mendapatkan keuntungan karena biaya untuk produksi serta perawatan mesin lebih murah.

Perusahaan dapat mempertimbangkan alternatif penggantian mesin baru dengan mengusulkan skim pembiayaan yang sesuai. Setelah dilakukan penggantian mesin, perusahaan dapat memperbaiki sistem operasi dengan mengacu pada mesin baru yang dibeli.

\section{DAFTAR PUSTAKA}

1. Afandi. (2009). Analisis Studi Kelayakan Investasi Pengembangan Usaha Distribusi PT. Aneka Andalan Karya. Jurnal Ekonomi. Vol. 1. No. 2:11-13.

2. Halim, A. (2005). Analisis Investasi. Salemba Empat: Jakarta.
3. Kasmir dan Jakfar. (2007). Studi Kelayakan Bisnis. Edisi 2. Kencana: Jakarta.

4. Mukti. (2009). Analisis Kelayakan Investasi Pabrik Kelapa Sawit Studi Kasus Kabupaten Aceh Utara, Naggroe Aceh Darussalam. Institut Pertanian Bogor: Bogor. Skripsi Manajemen Agribisnis. Vol. 1 No. 2:24-26.

5. Pujawan, I. N. (2008). Ekonomi Teknik. Cetakan Ketiga. Surabaya: Guna Widya.

6. Subagyo, A. (2008). Studi Kelayakan Teori dan Aplikasi. PT Elex Media Komputindo: Jakarta.

7. Umar, H. (2005). Studi Kelayakan Bisnis. PT. Gramedia Pustaka Utama: Jakarta

8. Widiyanthi, F. (2007). Analisis Kelayakan Investasi Penambahan Mesin Vacuum Frying Untuk Usaha Kecil Pengolahan Kacang Studi Kasus Di PD. Barokah Cikuing Majalengka Jawa Barat. Institut Pertanian Bogor: Bogor. Skripsi Manajemen Agribisnis. Vol. 2. No.3:24-27. 